\title{
T CD4+ CELLS COUNT AMONG PATIENTS CO-INFECTED WITH HUMAN IMMUNODEFICIENCY VIRUS TYPE 1 (HIV-1) AND HUMAN T-CELL LEUKEMIA VIRUS TYPE 1 (HTLV-1): HIGH PREVALENCE OF TROPICAL SPASTIC PARAPARESIS/HTLV-1-ASSOCIATED MYELOPATHY (TSP/HAM)
}

\author{
Jorge CASSEB(1,2), Maria Paulina POSADA-VERGARA(1), Patrícia MONTANHEIRO(2), Lígia Maria Ichii FUKUMORI(2), Ingrid OLAH(2), Jerusa SMID(1),
} Alberto José da Silva DUARTE(2) \& Augusto Cesar PENALVA DE OLIVEIRA(1)

\begin{abstract}
SUMMARY
Introduction: HIV positive patients co-infected with HTLV-1 may have an increase in their T CD4 ${ }^{+}$cell counts, thus rendering this parameter useless as an AIDS-defining event. Objective: To study the effects induced by the co-infection of HIV-1 and HTLV-1 upon CD4 ${ }^{+}$cells. Material and Methods: Since 1997, our group has been following a cohort of HTLV-1-infected patients, in order to study the interaction of HTLV-1 with HIV and/or with hepatitis C virus (HCV), as well as HTLV-1-only infected asymptomatic carriers and those with tropical spastic paraparesis/HTLV-1 associated myelopathy (TSP/HAM). One hundred and fifty HTLV-1infected subjects have been referred to our clinic at the Institute of Infectious Diseases "Emílio Ribas", São Paulo. Twenty-seven of them were also infected with HIV-1 and HTLV-1-infection using two ELISAs and confirmed and typed by Western Blot (WB) or polymerase chain reaction (PCR). All subjects were evaluated by two neurologists, blinded to the patient's HTLV status, and the TSP/HAM diagnostic was based on the World Health Organization (WHO) classification. AIDS-defining events were in accordance with the Centers for Disease Control (CDC) classification of 1988. The first T CD4+ cells count available before starting antiretroviral therapy are shown compared to the HIV-1-infected subjects at the moment of AIDS defining event. Results: A total of 27 HIV-1/HTLV-1 co-infected subjects were identified in this cohort; 15 already had AIDS and 12 remained free of AIDS. The median of T CD4+ cell counts was 189 (98-688) cells $/ \mathrm{mm}^{3}$ and 89 (53-196) cells $/ \mathrm{mm}^{3}$ for co-infected subjects who had an AIDSdefining event, and HIV-only infected individuals, respectively $(p=0.036)$. Eight of 27 co-infected subjects $(30 \%)$ were diagnosed as having a TSP/HAM simile diagnosis, and three of them had opportunistic infections but high T CD4 ${ }^{+}$cell counts at the time of their AIDS- defining event. Discussion: Our results indicate that higher T CD4+ cells count among HIV-1/HTLV-1-coinfected subjects was found in $12 \%$ of the patients who presented an AIDS-defining event. These subjects also showed a TSP/HAM simile picture when it was the first manifestation of disease; this incidence is 20 times higher than that for HTLV-1-only infected subjects in endemic areas.
\end{abstract}

KEYWORDS: HTLV-I; HIV-1; Co-infection; Neurological manifestation; TSP/HAM simile.

\section{INTRODUCTION}

Although the definition of AIDS requires a T CD4 cell count of less than 200 cells $/ \mathrm{mm}^{3}$, or the appearance of certain opportunistic disease manifestations, it has been demonstrated that co-infection with human T-cell lymphotropic virus type 1 (HTLV-1) in a patient with human immunodeficiency virus type 1 (HIV-1)-infection may increase the $\mathrm{T} \mathrm{CD}^{+}$cell count, thus masking an AIDS-defining event ${ }^{13}$. These findings are in accordance with several publications relating this phenomenon ${ }^{1,3,6,11}$. In fact, HIV-1/HTLV-1 co-infection may occur among $10 \%$ of the HIV-1-infected population ${ }^{6,15}$. Despite these findings, there is some controversy about whether the $\mathrm{T} \mathrm{CD} 4^{+}$cells counts remain clinically important in endemic areas where the two retroviruses are co-circulating.

\section{MATERIAL AND METHODS}

Since 1997, our group has been following a cohort to study HTLV1 interaction with HIV, as well as asymptomatic HTLV-1-only infected carriers and also patients with tropical spastic paraparesis/HTLV-1associated myelopathy (TSP/HAM). 150 HTLV-1-infected individuals were referred to our clinic at the Institute of Infectious Diseases "Emílio Ribas", São Paulo, the largest infectious diseases-specialized hospital in the city. Twenty-seven of them were diagnosed as co-infected with HIV-1 and HTLV-1-infection using two ELISAs (HTLV-1/2 capture EIA, Ortho Diagnostics, USA; and Murex HTLV-I/II, Abbott, USA), confirmed and typed by Western-Blot (HTLV 2.4, DBL, Singapore) or by polymerase chain reaction ${ }^{15}$. All subjects were evaluated by two neurologists, blinded to the patients' HTLV status, and the TSP/HAM 


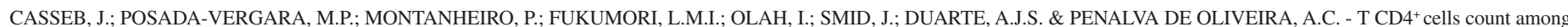
patients co-infected with human immunodeficiency virus type 1 (HIV-1) and human T-cell leukemia virus type 1 (HTLV-1): high prevalence of tropical spastic paraparesis/HTLV-1associated myelopathy (TSP/HAM). Rev. Inst. Med. trop. S. Paulo, 49(4):231-233, 2007.

diagnoses were based on WHO classification ${ }^{12}$. Centers for Disease Control (CDC) criteria were used for defining AIDS events ${ }^{5}$. The HIV1-only infected subjects belonged to a cohort that we have been following at Hospital das Clinicas for up to 20 years. This study population includes $233 \mathrm{HIV}$-1-infected subjects who were enrolled on a cohort aimed to describe the natural history of HIV infection in São Paulo, a study conducted at the outpatient service of the Secondary Immunodeficiencies Clinic of Hospital das Clínicas da Faculdade de Medicina da Universidade de São Paulo. The first cases were recruited in October 1987 and the last ones in December 2005. Patients were seen at the clinic at time intervals not longer than six months, usually less. Cut-off date for the current analysis was February 15, 2006 $6^{4,7}$. The first $\mathrm{T} \mathrm{CD}^{+}$cells count available before starting anti-retroviral therapy and at the moment of an AIDS defining event are shown compared to the HIV-1-infected subjects in this cohort. A total of 44 incident cases of AIDS were detected on this population.

Statistical analysis: Differences in patients' characteristics or laboratory values among the groups were evaluated with the one-way Mann-Whitney test. In both cases $p$ values $<0.05$ were considered statistically significant, and the $\chi^{2}$ test with Yates's correction was used to analyze and correlate the variables.

\section{RESULTS}

Table 1 describes the demographical and immunological characteristics of the subjects. The medians and respective interquartile ranges CD4 counts were $189(98-688)$ cells $/ \mathrm{mm}^{3}$ for co-infected subjects and 89 (53-196) cells $/ \mathrm{mm}^{3}$ for the HIV-infected group ( $p=$

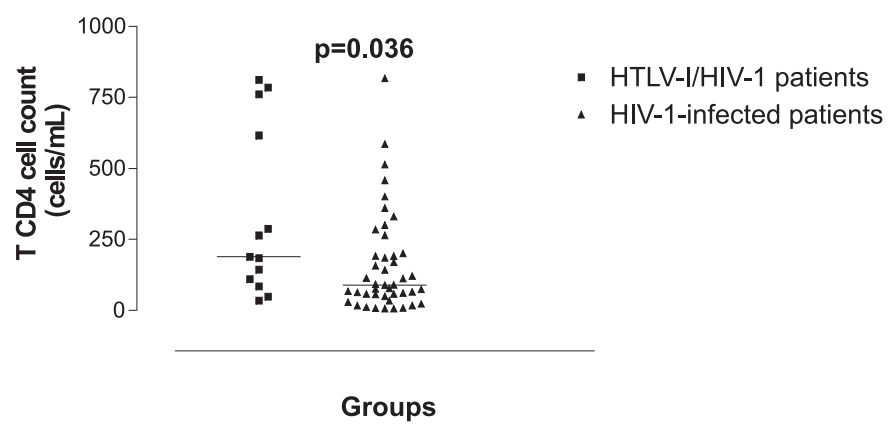

Fig. 1 - Differences between HTLV-I/HIV-1 and HIV-1-infected patients.
0.036). Five of 15 co-infected subjects (33\%) with AIDS were diagnosed as having TSP/HAM simile. Also, three of 12 asymptomatic HIV-1/HTLV1 patients showed the same clinical picture. Four patients of the coinfected group and six out of 44 AIDS non-coinfected subjects presented higher $\mathrm{T} \mathrm{CD}^{+}$cells count at the moment of the AIDS defining event.

\section{DISCUSSION}

The HIV-1/HTLV-1-coinfected group of patients showed higher T $\mathrm{CD}^{+}{ }^{+}$cells count compared to those HIV-1-only infected subjects at the time of an AIDS defining event. These findings are in accordance

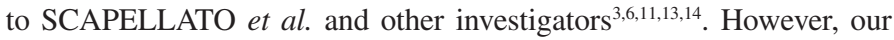
results should be seen with caution since our patients have been referred and selection bias cannot be ruled out in our cohort. Also, if we only consider patients with T CD4 ${ }^{+}$cells count above 500 cells $/ \mathrm{mm}^{3}$, the co-infected group showed no statistical significant difference at the time of appearance of opportunistic infection. Furthermore, HTLV-1infection disease progression, since some patients showed TSP/HAMlike diagnosis, as the first manifestation of the disease. However, this incidence is 20 times higher than that observed for HTLV-1-only infected subjects in endemic areas ${ }^{9}$. Finally, our data support the notion that HTLV-1/HIV-1 coinfection is related to an increase on the T CD4 ${ }^{+}$ cells count for some patients and may increase the risk for TSP/HAM development ${ }^{1,2,8}$. It is reasonable to think that in three of eight coinfected subjects, a TSP/HAM-simile diagnosis was the first clinical manifestation, indicating that up-regulation of the tax gene of HTLV-1 was the potential cause of TSP/HAM development. Moreover, it is conceivable that higher $\mathrm{T} \mathrm{CD}^{+}$cell counts, seen in $30 \%$ of co-infected subjects, may be the result of stimuli produced by some HTLV-1 proteins, thus masking the apoptosis induced by the HIV-1 infection ${ }^{10}$.

\section{RESUMO}

\section{Contagens de células T CD4+ ${ }^{+}$na co-infecção HIV-1 e HTLV-1: alta prevalência da paraparesia espástica tropical/mielopatia associada ao HTLV-1}

Introdução: A possibilidade que a co-infecção pelo vírus da leucemia de células T humana do tipo 1 (HTLV-1) em indivíduos infectados pelo vírus da imunodeficiência humana do tipo 1 poderia falsamente elevar o número de linfócitos $\mathrm{T} \mathrm{CD}^{+}{ }^{+}$no momento do evento definidor de aids, inferindo que essa contagem poderia ser um marcador laboratorial incompleto nos pacientes com a co-infecção HIV-1/HTLV-1.

Table 1

Age, men/women ratio, and CD4 cell counts among HIV-1-infected HIV-1 and HIV-1/HTLV-1-infected subjects

\begin{tabular}{|c|c|c|c|c|}
\hline & \multicolumn{2}{|c|}{ HIV-1+/HTLV-1 coinfected } & \multirow{3}{*}{$\begin{array}{c}\text { HIV-only-infected } \\
\text { patients with AIDS } \\
\text { Group C }\end{array}$} & \multirow{3}{*}{$\begin{array}{l}p \text { value } \\
\mathrm{B} \text { vs } \mathrm{C}\end{array}$} \\
\hline & HIV-1 infection without AIDS & AIDS & & \\
\hline & Group A & Group B & & \\
\hline N. & 12 & 15 & 44 & \\
\hline Men/women & $8 / 4$ & $12 / 3$ & $34 / 10$ & NS \\
\hline Mean age $(y) \pm S D$ & $40 \pm 5$ & $40 \pm 7$ & $38 \pm 9$ & NS \\
\hline Median T CD4 $4^{+}$cell count $(\text {cells } / \mathrm{mL})^{*}$ & $895(735-1603)$ & $189(98-688)$ & $89(53-196)$ & $p=0.036$ \\
\hline TSP/HAM simile (n.) & 3 & 5 & 0 & 0.70 \\
\hline
\end{tabular}

* $\mathrm{T} \mathrm{CD}^{+}$cells count at the time of an AIDS clinical defining event (CDC, 1988), or at the first visit to the HTLV out-clinic. Results shown in median and interquartile range in parenthesis. 


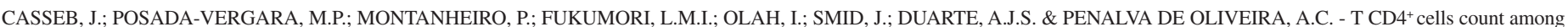

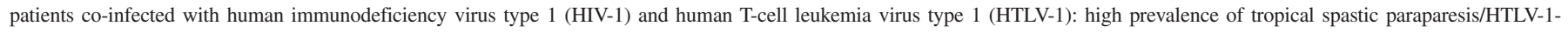
associated myelopathy (TSP/HAM). Rev. Inst. Med. trop. S. Paulo, 49(4):231-233, 2007.

Objetivo: Estudar a interação entre o HIV-1 e a co-infecção como o HTLV-1. Material e método: Desde 1997, nosso grupo tem seguido uma coorte de pacientes para estudar a interação entre HIV e/ou vírus da hepatite $\mathrm{C}(\mathrm{HCV})$, como também pacientes assintomáticos ou com TSP/HAM. 150 pacientes infectados pelo HTLV-1, encaminhados à clínica de HTLV do Instituto de Infectologia Emilio Ribas, São Paulo, Brasil, foram estudados. Vinte e sete deles estavam co-infectados pelo HIV-1 e HTLV-1, usando dois ELISAs e confirmados tipados pelo WB ou PCR. Todos os pacientes foram avaliados por dois neurologistas, cegos para o status de HTLV e o diagnóstico de TSP/HAM foi baseado na classificação da Organização Mundial de Saúde, 1988. A primeira contagem de células $\mathrm{T}$ disponível antes da terapia anti-retroviral foi mostrada para comparar com os pacientes infectados pelo HIV no momento do evento definidor de aids de acordo com Classificação do Centro de controle de Doenças, 1988. Resultados: Um total de 27 HIV-1/HTLV-1 co-infectados foram identificados na coorte, 15 já apresentavam aids e 12 permaneceram sem evento de aids. A mediana de células T CD4 foi de 189 (98-688) células $/ \mathrm{mm}^{3}$ e 89 (53-196) células/ $\mathrm{mm}^{3}$ nos co-infectados que tinham evento definidor de aids e naqueles com a infecção somente pelo HIV, respectivamente $(p=0,036)$. Oito dos 27 co-infectados (30\%) foram diagnosticados tendo TSP/HAM símile, e três deles mostraram elevada contagem de células T CD4 e apresentaram infecções oportunistas no momento do evento definidor de aids. Discussão: Nossos resultados indicam que a contagem de células T $\mathrm{CD}^{+}{ }^{+}$entre os indivíduos com HIV-1/HTLV-1 foi somente discrepante em $12 \%$ desses pacientes e podem ser relacionados à progressão da infecção HTLV-1, e todos mostraram um quadro de TSP/ HAM símile como a primeira manifestação de doença. Entretanto, essa taxa de ataque foi 20 vezes mais alta que a observada em pacientes somente infectados pelo HTLV-1 em área endêmica.

\section{ACKNOWLEDGEMENTS}

The authors thank Dana Gallo for the helpful discussion, all patients who participated in this study, and the financial support provided by Fapesp 99/11188-1, 03/08901-5, CNPq, No. 03/00841-3, Fundação Faculdade de Medicina.

\section{REFERENCES}

1. BEILKE, M.A.; GREENSPAN, D.L.; IMPEY, A.; THOMPSON, J. \& DIDIER, P.J. Laboratory study of HIV-1 and HTLV-I/II coinfection. J med. Virol., 44: 132-143, 1994

2. BERGER J.R.; RAFFANTI, S.; SVENNINGSSON, A. et al. - The role of HTLV in HIV1 neurologic disease. Neurology, 41: 197-202, 1991.
3. CASSEB, J.; HONG, M.A.; SALOMÃO, S. et al - Coinfection with human immunodeficiency virus and human T-cell lymphotropic virus type I: reciprocal activation with clinical and immunologic consequences. Clin. infect. Dis., 25: 12591260, 1997.

4. CASSEB, J.; MARCONDES, L.A.,;VEIGA, A.P.R. et al. - AIDS incidence and mortality in a hospital-based cohort of HIV-1-seropositive patients receiving highly active antiretroviral therapy in São Paulo, Brazil. AIDS Patient Care STDs, 17: 447-452, 2003.

5. CENTERS FOR DISEASE CONTROL AND PREVENTION - Revision of the surveillance case definition for acquired immunodeficiency syndrome. M.M.W.R., 6 (suppl. 1S): 1S-15S, 1987.

6. FANTRY, L.; DE JONGE, E.; AUWAERTER, P.G. \& LEDERMAN, H.M. Immunodeficiency and elevated CD4 T lymphocyte counts in two patients coinfected with human immunodeficiency virus and human lymphotropic virus type I. Clin. infect. Dis., 21: 1466-1468, 1995.

7. FONSECA, L.A.; REINGOLD, A.L.; CASSEB, J.; BRÍGIDO, L.F.M. \& DUARTE A.J.S. - AIDS incidence and survival in a hospital-based cohort of asymptomatic HIV patients in São Paulo, Brazil. Int. J. Epidem., 28: 1156-1160, 1999.

8. HARRISON, L.H.; VAZ, B.; TAVEIRA, D.M. et al. - Myelopathy among Brazilians coinfected with human T-cell lymphotropic virus type I and HIV. Neurology, 48 13-18, 1997.

9. KAPLAN, J.E.; OSAME, M.; KUBOTA, H. et al. - The risk of development of HTLV-Iassociated myelopathy/tropical spastic paraparesis among persons infected with HTLV-I. J. acquir. Immune Defic. Syndr., 3: 1096-1101, 1990.

10. MOON, H.S. \& YANG, J.S. - Role of HIV Vpr as a regulator of apoptosis and an effector on bystander cells. Mol. Cells, 21: 7-20, 2006.

11. NADLER, J.P.; BACH, M.C. \& GODOFSKY, E. - Management of coinfection with human immunodeficiency virus and human T-cell lymphotropic virus type I. Clin. infect. Dis., 23: 415, 1996.

12. OSAME, M. - HTLV. In: BLATTNER, W.A., ed. Human retrovirology: HTLV. New York, Raven Press, 1990. p. 191-197.

13. SCAPELLATO, P.G.; BOTTARO, E.; RODRIGUEZ-BRIESCHKE M.T. et al. - CD4 cell count among HIV-infected patients with an AIDS-defining disease: higher count in patients coinfected than in those not coinfected with human T-cell lymphotropic virus type I. J. acquir. Immune Defic. Synd., 33: 279-280, 2003.

14. SCHECHTER, M.; HARRISON L.H.; HALSEY, N.A. et al. - Co-infection with human T-cell lymphotropic virus type I and HIV in Brazil: impact on markers of HIV disease progression. J. Amer. med. Ass., 271: 353-357, 1994.

15. TUKE, P.W.; LUTON, P. \& GARSON, J.Á. - Differential diagnosis of HTLV-I and HTLVII infections by restriction enzyme analysis of "nested" PCR products. J. virol. Meth., 40: 163-174, 1992.

Received: 22 June 2006

Accepted: 5 March 2007 